\title{
Spectroscopic Studies of the Quality of Fatty Acid Methyl Esters Derived from Waste Cooking Oil
}

\author{
Arkadiusz Matwijczuk ${ }^{1 *}$, Grzegorz Zając ${ }^{2 * *}$, Radosław Kowalski³ \\ Magdalena Kachel-Jakubowska ${ }^{4}$, Mariusz Gagośs \\ ${ }^{1}$ Department of Biophysics, University of Life Sciences in Lublin, \\ Akademicka 13, 20-950 Lublin, Poland \\ ${ }^{2}$ Department of Power Engineering and Transportation, University of Life Sciences in Lublin, \\ Głęboka 28, 20-612 Lublin, Poland \\ ${ }^{3}$ Department of Analysis and Food Quality Assessment, University of Life Sciences in Lublin, \\ Skromna 8, 20-704 Lublin, Poland \\ ${ }^{4}$ Department of Machinery Exploitation and Management of Production Processes, \\ University of Life Sciences in Lublin, Faculty of Production Engineering \\ ${ }^{5}$ Department of Cell Biology, Institute of Biology, Maria Curie-Skłodowska University, \\ 20-033 Lublin, Poland
}

Received: 26 January 2017

Accepted: 12 April 2017

\begin{abstract}
Biodiesel is a very attractive, biodegradable, renewable, and virtually nontoxic form of fuel. It is derived through base-catalysed transesterification of vegetable oils or animal fats. Analysis of biodiesel has become relevant, since the higher quality of the fuel is a key factor in commercialisation and market acceptance. The analytical methods employed are being constantly improved to meet this requirement. The most popular techniques for analysis of biodiesel include mainly chromatography and molecular spectroscopy. FTIR infrared spectroscopy is one of the most important spectroscopic techniques.

The article presents the results of UV-Vis absorption spectroscopy and FTIR infrared spectroscopy analysis employed for investigating methyl esters of higher fatty acids obtained with laboratory methods from selected sunflower and rapeseed oils and waste animal fats provided by a slaughterhouse. Commercial methyl esters were included in the analyses for comparison. In all samples, the contents of free glycerol, methanol, esters, and linolenic acid methyl ester in FAME were determined mainly to facilitate the spectroscopic analysis. The results of the investigations conducted with the aforementioned methods clearly indicate that the analysed WCO esters can be successfully used as potential industrial-scale biofuels.
\end{abstract}

Keywords: molecular spectroscopy (FTIR, UV-Vis), biodiesel, fatty acid methyl esters (FAME), waste cooking oil (WCO)

\footnotetext{
*e-mail: arkadiusz.matwijczuk@up.lublin.pl,arekmatwijczuk@gmail.com

**e-mail: grzegorz.zajac@up.lublin.pl
} 


\section{Introduction}

The development of combustion engines is associated with the use of crude oil as an energy source. For more than a hundred years of the history of motorization, hydrocarbon fractions from crude oil have served as the only fuel. Crude oil is still the most important energy source with a powerful impact on the political and economic situations in many countries worldwide. However, the modern world has realised both the possibility of rapid depletion of oil resources and the serious ecological threat, i.e., $\mathrm{CO}_{2}$ emissions, which are strongly related to the use of various types of vehicles. This has become a driving force behind many research programs focused on the search for fuels that would partially or entirely replace conventional fuels derived from crude oil and pose only an inconsiderable threat to the natural environment [1-3]. An important role is played by fuels produced from renewable sources, i.e., biofuels, with currently the most attractive biodiesel defined as fatty acid methyl esters (FAME) [4]. The use of FAME as a fuel for compression-ignition engines or as a component of diesel fuel substantially changes the properties of the fuels currently used in this type of engine. The different chemical structures of FAME and hydrocarbons contained in the diesel fuel largely determines the behaviour of the two products in the engine chamber and in storage.

Any vegetable or animal fats can be used as a raw material for production of biodiesel [5-6]. Currently, edible vegetable oils [7], e.g., rapeseed, sunflower [8], soybean [9], and palm oils, are most commonly used for biodiesel production. However, the use of these first-generation raw materials does not solve the major problems associated with reduction of $\mathrm{CO}_{2}$ emissions, but considerably exacerbates food market problems [1012]. Therefore, attention is currently focused on secondgeneration raw materials: oils from inedible plants such as algae and microalgae [13], Jatropha [14], or waste cooking oils (WCO) [1, 15] from households and restaurants.

WCO [4, 16-19] is regarded as the most promising raw material for biodiesel production $[4-5,16]$, as indicated by two major factors: its wide availability and low cost [20]. The amount of WCO generated by households and restaurants is increasing rapidly as consumption grows. The United States alone generates approximately 10 million tons of WCO annually, which requires economically and environmentally friendly disposal methods; utilisation thereof as a raw material in biodiesel production is one such method [10]. The low cost of obtaining WCO may help to overcome a major barrier in the development of biodiesel production - the ca. 1.5 -fold higher production cost in comparison with the cost of conventional diesel production. A number of studies have shown that approximately $70-75 \%$ of biodiesel production cost is accounted for by raw materials [21]. The price of WCO is two to three times lower than that of crude vegetable oils, which reduces the cost of biodiesel production. The lower cost of waste disposal should also be underlined [5].
The chemical and physical properties of WCO differ from the properties of fresh oil due to the changes occurring during the frying process [11], when high temperatures $\left(170-190^{\circ} \mathrm{C}\right)$ in the presence of oxygen and water contained in the fried food cause many physical and chemical transformations in the food and the frying medium. These transformations can result in the synthesis of a number of various compounds, often exhibiting a complex and not always specified structure, e.g., free fatty acids (FFA) [11, 22]. Furthermore, the presence of solid substances in the products and water contained in the fried products or introduced through washing may constitute a problem. The fatty acid [23-24] profile and the composition of free fatty acids contained in the raw materials exert an effect on the physicochemical properties of produced biofuels. Water, impurities [2526], and unsaponifiable matter reduce the yield of the transesterification reaction and, consequently, the quality of the biofuel. The use of WCO as a raw material for biodiesel production necessitates the application of adequate technologies with pre-treatment processes and a selection of appropriate transesterification parameters. The products obtained should be monitored with appropriate techniques, e.g., FTIR infrared spectroscopy [27-29], which is one of the most effective methods [2].

The aim of the investigations presented in this paper was to show and compare the physico-chemical properties of WCO-derived methyl esters, which can be used as biofuels (both as fuels and as additives to diesel fuels) [30]. The main objective of the study was to compare the selected WCO-derived esters with those obtained from pure vegetable oils and commercial ester with the use of electronic absorption spectroscopy and analysis of FTIR infrared spectra. The investigations were divided into two parts: the first part focused on analysis of the products to determine the content of esters, methanol, and glycerol $[6,8,31-32]$; the second part involved spectroscopic analysis [33] - primarily infrared spectroscopy (FTIR).

\section{Materials and Methods}

\section{Materials}

The analyses were carried out on fatty acid methyl esters derived with laboratory methods from fresh oils, waste cooking oils (WCO [21]), and waste animal fats as well as commercial biodiesel B100 meeting the requirements of the EN 14214:2006 standard. The following raw materials were used:

1. Refined sunflower oil [8].

2. Refined sunflower oil subjected to five cycles of frying of potato chips; a single cycle consisted of heating the oil to $180^{\circ} \mathrm{C}$ and frying the product.

3. Refined sunflower oil subjected to five cycles of frying fish "fingers"; a single cycle consisted of heating the oil to $180^{\circ} \mathrm{C}$ and frying the product.

4. Refined sunflower oil subjected to five cycles of heating in similar conditions to those characteristic for 
the frying process in small catering premises; a single cycle consisted of heating the oil to $180^{\circ} \mathrm{C}$ followed by maintaining this temperature for $10 \mathrm{~min}$ and cooling the oil to room temperature.

5. Degummed and filtered rapeseed oil extracted by mechanical pressing.

6. Waste animal fats provided by a slaughterhouse; the fats were melted by slow heating to $60^{\circ} \mathrm{C}$ (under reduced pressure to avoid degradation); in order to remove residues, the melted fats were filtered, centrifuged, and decanted.

The raw materials were subjected to the process of esterification in a 1,000-ml laboratory reactor with regulation and stabilisation of the jacket temperature. The reaction time and stirring rate were determined experimentally or taken from the literature $[15,23,30$, 34].

The reaction was carried out at $55^{\circ} \mathrm{C}$. When the oils reached the intended temperature, a catalytic mixture consisting of methanol and $\mathrm{NaOH}$ was added to initiate the transesterification reaction. During the reaction, the mixture was stirred with a mechanical stirrer for $2 \mathrm{~h}$. Subsequently, the mixture was subjected to $8 \mathrm{~h}$ sedimentation for complete separation of glycerol and esters. The esters were rinsed twice with hot water $\left(80^{\circ} \mathrm{C}\right)$ and dried to remove alcohol and catalyst residues.

All esters were evaluated for their peroxide number (PN) (PN - ISO 3960), acid number (AN) (PN - ISO $660)$, and the composition of higher fatty acids. Fatty acid composition was determined by using the gas chromatography method. Chromatographic separation was carried out using a gas chromatograph with nitrogen as a carrier gas, a packed column (2.5 $\mathrm{m}$ with the PEGA stationary phase of polyethylene glycol adipate on a GAZ-ChROM-Q carrier), and a flame ionisation detector.

\section{Methods}

\section{Electronic Absorption Apectroscopy (UV-Vis)}

Electronic absorption spectra were recorded at $23^{\circ} \mathrm{C}$ on a double-beam UV-Vis spectrophotometer Cary 300 Bio (Varian, USA) equipped with a thermostatted cuvette holder with a 6x6 multi-cell Peltier block. The temperature was controlled with a thermocouple probe (Cary Series II, Varian, USA) placed directly in the quartz cuvette. The spectra were recorded from 200 to 600 nm.

\section{FTIR Measurements}

The measurements of ATR-FTIR background-corrected spectra were carried out in solvents using an HATR Ge trough $\left(45^{\circ}\right.$ cut yielding 10 internal reflections) crystal plate for liquids and were recorded with a 670-IR spectrometer (Varian, USA). Typically, 25 scans were collected, Fourier-transformed, and averaged for each measurement. The IR absorption spectra at a resolution of one data point per $1 \mathrm{~cm}^{-1}$ were obtained in the region between 4,000 and $400 \mathrm{~cm}^{-1}$. The instrument was purged with argon for $40 \mathrm{~min}$ before and during the measurements. The Ge crystal was cleaned with ultra-pure organic solvents (Sigma-Aldrich Co.). All experiments were carried out at $20^{\circ} \mathrm{C}$.

\section{Results and Discussion}

FTIR is commonly used for analyzing carbonyl compounds and determination their presence in petroleum products [35]. The potential of the application of the technique for determining FAME content in diesel fuel has been evidenced in the literature. It is associated with the fact that absorption in the $\mathrm{C}=\mathrm{O}$ [36-37] carbonyl group band $\left(1,700-1,800 \mathrm{~cm}^{-1}\right)$ in hydrocarbon fractions is relatively low or absent, whereas absorption of FAME in this region is very intense.

Esters produce characteristic, very strong absorption bands generated by $\mathrm{C}=\mathrm{O}$ and $\mathrm{C}-\mathrm{O}$ valence vibrations. The $\mathrm{C}=\mathrm{O}$ absorption band of saturated aliphatic esters is in the range of $1,735-1,750 \mathrm{~cm}^{-1}$ [24, 38-39]. Aryl and $\alpha, \beta$-unsaturated structures cause its slight shift towards lower wavenumber values $\left(1,715-1,730 \mathrm{~cm}^{-1},[39]\right)$. C-O stretching vibrations lead to the appearance of a broad 1,100-1,300 $\mathrm{cm}^{-1}$ band, which can also be observed in the spectra of ethers, acids, and alcohols [7, 24, 39]. The methyl esters of long-chain fatty acids exhibit three absorption bands: 1,250, 1,205, and $1,175 \mathrm{~cm}^{-1}[24,40]$. The band at $1,175 \mathrm{~cm}^{-1}$ in this range is most visible in the FAME spectrum. The other bands observed in the FTIR spectrum are typical of the hydrocarbon chain structures present both in FAME and diesel fuel [40-41]:

Stretching vibrations of the $\mathrm{C}-\mathrm{H}$ bond: the methyl group $\left(v \mathrm{CH}_{3}\right)$ at wavelengths of ca. 2,870 and $2,965 \mathrm{~cm}^{-1}$ and the methylene group $\left(\mathrm{v} \mathrm{CH}_{2}\right)$ at wavelengths of ca. 2,850 and 2,925 $\mathrm{cm}^{-1}$ (symmetric and asymmetric, respectively, in both cases) [24, 42].

Deformation vibrations of the $\mathrm{C}-\mathrm{H}$ bond: the methyl group $\left(\delta \mathrm{CH}_{3}\right)$ at wavelengths of 1,375 and $1,450 \mathrm{~cm}^{-1}$ $\left(1,438 \mathrm{~cm}^{-1}\right.$ in compounds with a carbonyl group) and the methylene group $\left(\delta \mathrm{CH}_{2}\right)$ at wavelengths of 1,465 (scissoring vibrations) and $721 \mathrm{~cm}^{-1}$ (rocking vibrations) [43].

The appearance of bands at a wavelength range of $1,700-1,800 \mathrm{~cm}^{-1}$ in the hydrocarbon fraction of diesel fuel (not comprising FAME) may indicate the presence of oxidation products (aldehydes, ketones, carboxylic acids) or the presence of some oxidation inhibitors, e.g., imides. The weak absorption at the $1,750 \mathrm{~cm}^{-1}$ wavelength in the case of some diesel fuels may be attributed to the presence of low amounts (ca. 1\%) of depressants [44] (polymers with carbonyl groups). The probability of appearance of these carbonyl compounds is usually very low, in particular in high-quality fuels, but their presence can pose analytical difficulties in determining FAME in petroleum products [24].

In summary, despite the drawbacks mentioned above, the band at a wavelength of $1,750-1,740 \mathrm{~cm}^{-1}$ was regarded 
as the most optimal for identification and quantitative analysis of FAME in medium petroleum fractions [45] and lubricating oils [42].

Fig. 1 presents electronic absorption spectra for rapeseed oil methyl esters (Panel A), methyl esters of heated and non-heated sunflower oil (Panel B), and B100 solved in methanol (Panel C). The position of absorption peaks centred at ca. $270 \mathrm{~nm}$ for all the analysed oils (277 $\mathrm{nm}$ for rapeseed oil methyl esters, $279 \mathrm{~nm}$ for methyl esters of heated and non-heated sunflower oil, and $281 \mathrm{~nm}$ for B100) indicates an $\mathrm{n} \rightarrow \pi^{*}$ electron transition in the carbonyl group $(\mathrm{C}=\mathrm{O})[36,46]$. The presence of a broad absorption region located between $360 \mathrm{~nm}$ and $510 \mathrm{~nm}$ in the B100 electron absorption spectra, which is not visible in the case of the other analysed esters, is worth noting. The region between $360 \mathrm{~nm}$ and $510 \mathrm{~nm}$ appearing only in the case of B100 may be associated with

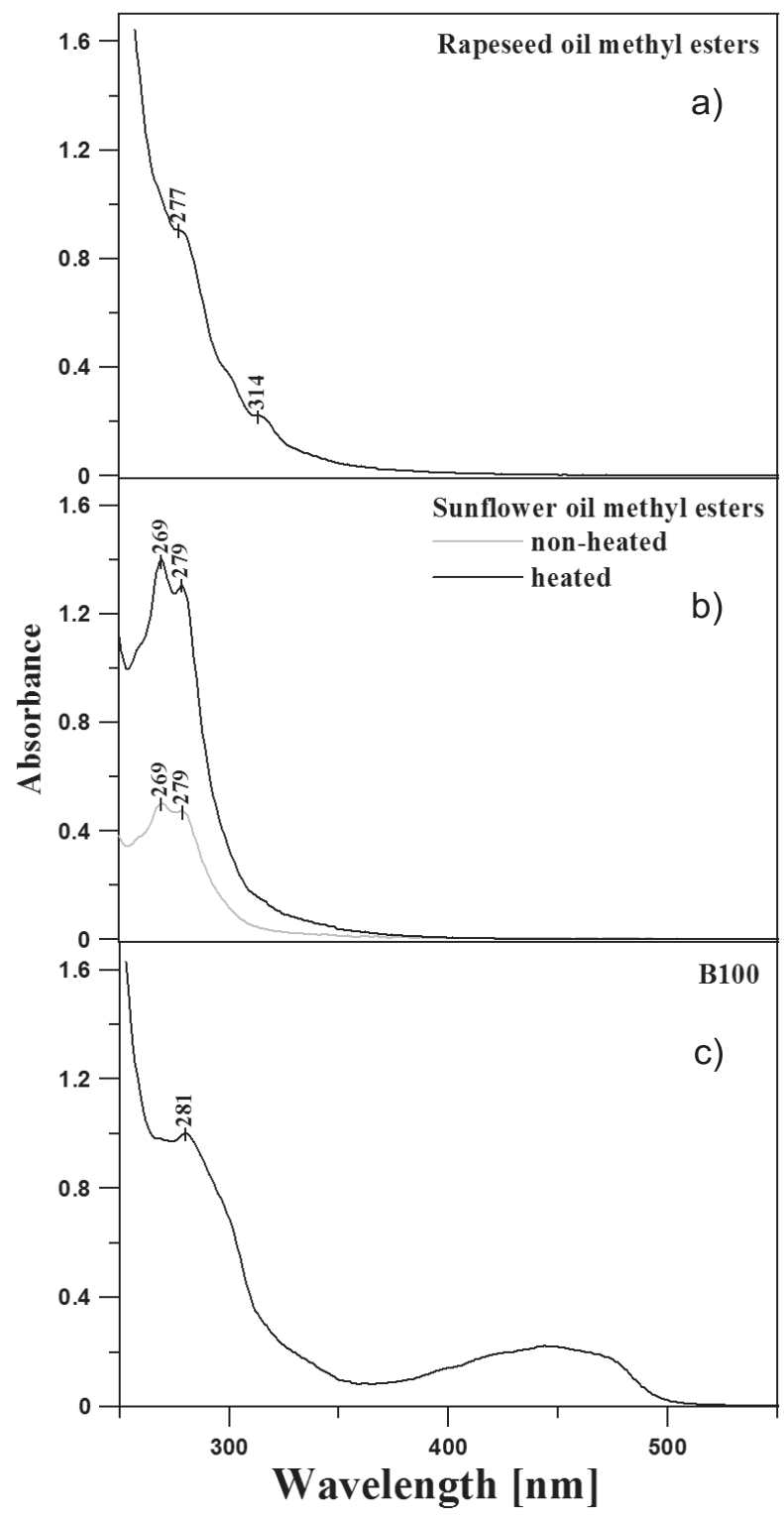

Fig. 1. Electronic absorption spectra of rapeseed oil methyl esters (Panel a), heated and unheated sunflower oil methyl esters (Panel b), and B100 (Panel c) dissolved in $\mathrm{Mt}-\mathrm{OH}$ the presence of various types of additives present in these fuels, i.e. synthetic or natural compounds, e.g. biocides [46]. The clear band at $314 \mathrm{~nm}$ may indicate the presence of small amounts of various types of additives or other impurities in the rapeseed oil methyl esters, while the analysed sunflower oil methyl esters are virtually devoid of such additives (Fig. 1, Panel B). Similar analyses performed for other types of esters (data not shown) show that their properties are comparable to those of sunflower oil methyl esters (Fig. 1, Panel A).

Fig. 2 shows ATR-FTIR spectra of the analysed esters. The samples were deposited on a $\mathrm{ZnSe}$ crystal and evaporated in $\mathrm{N}_{2}$ atmosphere. It should be strongly emphasised that infrared spectroscopy methods are more frequently used by researchers for assessing the quality of new biofuel forms [29, 38-39, 47-48]. FTIR spectroscopy reveals characteristic spectral regions that provide an undeniable description of vibrations of functional groups demonstrating the quality of the analysed product $[2,28$ $29,33]$, as well as the molecular interactions between compounds and additives contained in the product [2, 47, 49]. The research methods employed in the study (in particular FTIR) allow for rapid comparison of the selected esters with commercially available biofuels [50].

A $\mathrm{C}=\mathrm{O}$ group band with a maximum at ca. 1,742 $\mathrm{cm}^{-1}\left(1,743 \mathrm{~cm}^{-1}\right.$ for the rapeseed oil methyl esters) can be seen for all the analysed esters [37-38]. Noteworthy are the distinct differences in the shape of the bands at $1,770-1,670 \mathrm{~cm}^{-1}$ in the spectrum of the heated and nonheated sunflower oil methyl esters (Fig. 2, Panel B). In the case of the non-heated sunflower oil methyl esters there is a decline in the intensity of the band at $1,742 \mathrm{~cm}^{-1}$ responsible for the $\mathrm{C}=\mathrm{O}$ group vibrations, in comparison with the esters from the heated oil. Concurrently, a band at $1,713 \mathrm{~cm}^{-1}$ appears, which is absent for the heated oil esters and which can be assigned to the formation of hydrogen bonds between groups $\mathrm{C}=\mathrm{O} \cdots \mathrm{H}-\mathrm{O}-\mathrm{H}$ [7]. No band at $1,713 \mathrm{~cm}^{-1}$ is observed either in the $\mathrm{B} 100$ spectrum or in the spectrum of the rapeseed oil methyl esters, which may suggest that no such structures are formed. Simultaneously with the decline in the intensity of the band at $1,742 \mathrm{~cm}^{-1}$ in the sunflower oil methyl esters and the appearance of a band at $1,713 \mathrm{~cm}^{-1}$, there is a clear increase in the intensity of the band at $1,030 \mathrm{~cm}^{-1}$, which is attributed to stretching vibrations in the $\mathrm{C}-\mathrm{O}$ group [7]. This band is also visible in the spectrum of the rapeseed oil methyl esters; it exhibits the weakest intensity in the B100 spectrum, which results in the greatest intensity of the carbonyl group band in these spectra. The $1,100-1,300 \mathrm{~cm}^{-1}$ region also corresponds to the stretching vibrations of the $\mathrm{C}-\mathrm{O}$ group and exhibits slight changes in the analysed esters and B100. The decrease in the affinity for hydrogen bonding between $\mathrm{C}=\mathrm{O} \cdots \mathrm{H}-\mathrm{O}-\mathrm{H}$ is accompanied by a slight increase in the intensity of these bands. A similar relationship is also evident in the case of B100. Attention should be paid to the very interesting region between 3,660 and $3,080 \mathrm{~cm}^{-1}$, with a peak at ca. $3,350 \mathrm{~cm}^{-1}$ evoked by the high content of methanol 


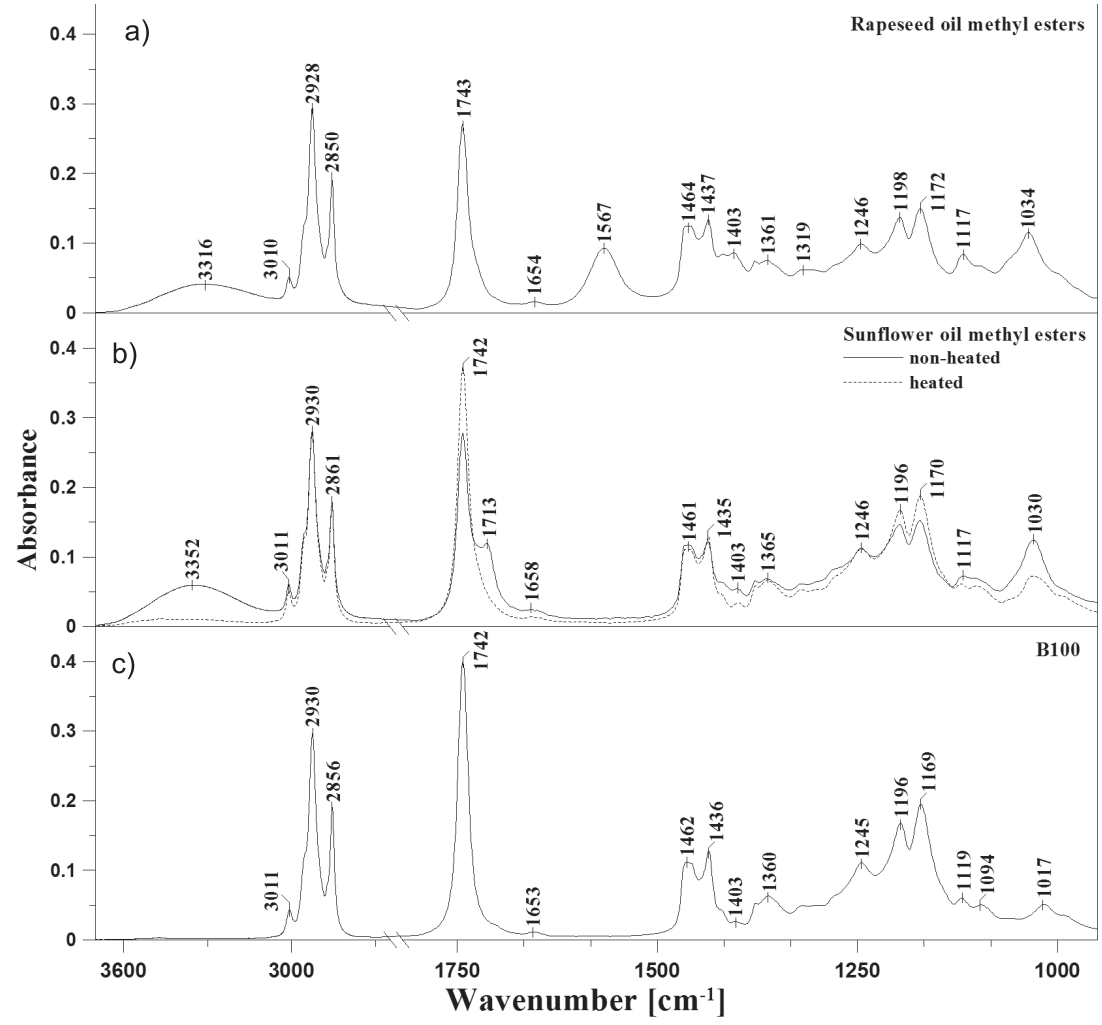

Fig. 2. ATR-FTIR absorption spectra of rapeseed oil methyl esters (Panel a), heated and unheated sunflower oil methyl esters (Panel b), and B100 (Panel c) dissolved in Mt-OH.

(Table 2) and $\mathrm{H}_{2} \mathrm{O}$ in a majority of the analysed esters. The water content in the analysed samples may imply the presence of different impurities contained therein [43] (small amounts of water that may affect the work of engines). The intensity of this region decreases with the declining methanol content in the esters and has the lowest value in B100. Importantly, the intensity of this region in the sunflower oil methyl esters decreases depending on whether the esters are subjected to the heating process or not.
These investigations of the content of free glycerol [42] in the analysed esters (Table 1) show its decline in the non-heated sunflower oil, heated sunflower oil, and B100, which exhibited the lowest amounts of the compound. A similar relationship regarding methanol content is visible in the analysed esters (Table 1); this correlates well with the decreasing intensity of the band at $3,352 \mathrm{~cm}^{-1}$ [7]. The total content of esters in the analysed samples and the content of linoleic acid methyl esters (Table 1) also correlated well with the level of band intensity at

Table 1. Contents of free glycerol, methanol, esters, and linolenic acid methyl ester in FAME for 1 -, 2 -, 3 -, 4 -, 5 -, 6 -, 7 -, 8 -, and 9 , respectively (explanation: see Materials and Methods).

\begin{tabular}{|c|c|c|c|c|c|c|}
\hline $\begin{array}{c}\text { Sample } \\
\text { no. }\end{array}$ & $\begin{array}{c}\text { Content of free } \\
\text { glycerol } \%(\mathrm{~m} / \mathrm{m})\end{array}$ & $\begin{array}{c}\text { Content of Mt-OH } \\
\%(\mathrm{~m} / \mathrm{m})\end{array}$ & $\begin{array}{c}\text { Content of esters } \\
(\%)\end{array}$ & SD & $\begin{array}{c}\text { Content of linolenic acid methyl ester } \\
(\%)\end{array}$ & SD \\
\hline 1 & 0.0000 & 0.46 & 90.30 & 1.56 & 5.75 & 0.07 \\
\hline 2 & 0.0017 & 1.09 & 83.60 & 0.14 & 5.20 & 0.00 \\
\hline 3 & 0.0162 & 1.37 & 84.80 & 0.57 & 5.60 & 0.00 \\
\hline 4 & 0.2374 & 1.79 & 72.95 & 0.21 & 5.35 & 0.07 \\
\hline 5 & 0.1972 & 2.39 & 66.55 & 0.07 & 1.10 & 0.00 \\
\hline 6 & 0.0287 & 1.55 & 85.30 & 0.42 & 1.20 & 0.00 \\
\hline 7 & 1.5906 & 1.93 & 53.00 & 0.00 & 1.30 & 0.14 \\
\hline 8 & 0.0300 & 1.25 & 87.00 & 0.28 & 8.60 & 0.00 \\
\hline 9 & 0.0069 & 0.19 & 94.30 & 0.14 & & 0.00 \\
\hline
\end{tabular}

$\mathrm{SD} \mathrm{m} / \mathrm{m}$ - standard deviation 
Table 2. Position of peaks of absorption bands with assignment of corresponding vibrations in the analysed biofuels (rapeseed oil methyl esters, heated and non-heated sunflower oil methyl esters, and commercial esters) in the spectral range of 3,700-900 $\mathrm{cm}^{-1}$.

\begin{tabular}{|c|c|c|c|c|}
\hline \multicolumn{4}{|c|}{ FTIR (Position of bands; $\mathbf{c m}^{-1}$ ) } & \multirow{3}{*}{ Type and origin of vibrations } \\
\hline \multirow{2}{*}{ Rapeseed oil methyl esters } & \multicolumn{2}{|c|}{ Sunflower oil methyl esters } & \multirow{2}{*}{ B100 } & \\
\hline & Heated & Non-heated & & \\
\hline 3,316 & $3,352 \mathrm{w}$ & $3,352 \mathrm{st}$ & - & $v(\mathrm{O}-\mathrm{H})$ in $\mathrm{H}_{2} \mathrm{O}$ \\
\hline 3,010 & 3,010 & 3,010 & 3,011 & $v(\mathrm{C}-\mathrm{H})$ \\
\hline 2,928 & 2,930 & 2,930 & 2,920 & \multirow{2}{*}{$\begin{array}{c}\mathrm{CH}_{2, \mathrm{~s}+\mathrm{as}}, \mathrm{CH}_{3, \text { s+as }} \text { aliphatic group of tri- } \\
\text { glycerides }\end{array}$} \\
\hline 2,850 & 2,861 & 2,861 & 2,856 & \\
\hline 1,743 & $1,742 \mathrm{st} / 1,713$ & $1,742 \mathrm{w}$ & $1,742 \mathrm{~s}$ & $\mathrm{C}=\mathrm{O}$ group of Ester \\
\hline 1,654 & 1,658 & 1,658 & 1,653 & $v(\mathrm{C}=\mathrm{C})$ \\
\hline 1,567 & - & - & - & $v(\mathrm{C}=\mathrm{C})_{\mathrm{s}}$ \\
\hline 1,464 & 1,461 & 1,461 & 1,462 & $-\mathrm{C}-\mathrm{H}\left(\right.$ in $\left.\mathrm{CH}_{2}\right)$ bending \\
\hline 1,437 & 1,435 & 1,435 & 1,436 & \multirow{2}{*}{$=\mathrm{C}-\mathrm{H}($ cis-) bending } \\
\hline 1,418 & 1,418 & 1,418 & 1,418 & \\
\hline $1,403 \mathrm{st}$ & $1,403 \mathrm{~m}$ & $1,403 \mathrm{~m}$ & $1,403 \mathrm{~m}$ & $v(=\mathrm{C}-\mathrm{H}($ cis- $))$ \\
\hline 1,377 & 1,377 & 1,377 & 1,377 & $-\mathrm{C}-\mathrm{H}_{\mathrm{s}}\left(\mathrm{in}_{\mathrm{CH}}\right)$ \\
\hline 1,361 & 1,365 & 1,365 & 1,360 & $-\mathrm{C}-\mathrm{H}_{\mathrm{s}}\left(\mathrm{CH}_{3}\right)$ bending \\
\hline 1,319 & 1,318 & 1,318 & 1,319 & $\delta(\mathrm{CH})$ \\
\hline $1,276 \mathrm{~m}$ & $1,276 \mathrm{st}$ & $1,276 \mathrm{st}$ & $1,276 \mathrm{~m}$ & $\delta\left(\mathrm{CH}_{2}\right)$ \\
\hline 1,246 & 1,246 & 1,246 & 1,245 & \multirow{2}{*}{$\begin{array}{l}-\mathrm{C}-\mathrm{O} \text { stretching } \\
\text { or }-\mathrm{O}-\mathrm{CH}_{2}-\mathrm{C}\end{array}$} \\
\hline 1,172 & 1,170 & 1,170 & 1,169 & \\
\hline 1,194 & 1,194 & 1,194 & 1,194 & $-\mathrm{C}-\mathrm{O}$ \\
\hline 1,117 & 1,117 & 1,117 & 1,119 & \multirow{2}{*}{$v(\mathrm{C}-\mathrm{C})$} \\
\hline 1,134 & 1,130 & 1,130 & 1,117 & \\
\hline 918 st & $915 \mathrm{~m}$ & $915 \mathrm{~m}$ & $910 \mathrm{~m}$ & $-\mathrm{OH}$ \\
\hline 859 & 859 & 859 & 859 & $v(\mathrm{C}-\mathrm{O}-\mathrm{C})_{\mathrm{s}}$ \\
\hline $840 w$ & 840 st & $840 \mathrm{st}$ & $840 w$ & $v(\mathrm{C}-\mathrm{O}-\mathrm{C})_{\mathrm{s}}$ or $v(\mathrm{C}-\mathrm{C})$ \\
\hline 722 & 722 & 722 & 722 & \\
\hline
\end{tabular}

$v$ - stretching vibrations, $\delta$ - deformation vibrations, $\mathrm{s}$ - symmetric, as - asymmetric, st - strong, ${ }^{*}$ denotes frequencies that may originate from the solvent used.

$3,352 \mathrm{~cm}^{-1}$, i.e., its intensity decreased with the increasing content of both components.

\section{Conclusions}

The aim of these investigations was to present the potential application of FTIR infrared spectroscopy for analysis of the quality of fatty acid methyl esters used as a fuel in combustion engines. The study mainly focused on methyl esters derived from WCO. The results were compared with the spectra of commercially available esters (B100), which meet the requirements of the EN 14214 standard. Moreover, the results obtained were compared with literature data; therefore, it will be possible in subsequent studies to carry out a rapid analysis of the quality of derived biofuels and waste by-products.

1. In the analysis of UV-Vis and FTIR infrared spectroscopy spectra, we investigated several important spectral regions that provided information about the suitability of the WCO-derived esters to be used as a biofuel in combustion engines.

2. A very important finding of the presented spectroscopic studies is the fact that FTIR infrared spectroscopy offers a rapid and cost-efficient analysis of the quality of potential biofuels.

It should also be underlined that both UV-Vis and FTIR studies provide a clear answer to the question of the quality 
of the investigated WCO-derived biofuels. Noteworthy is the fact that the components subjected to spectroscopic analysis seem to have comparable properties to those of the preparations used (biofuels). These investigations also suggest that in the near future biofuels may become a profitable and ecological alternative to the diesel biofuels used currently, which will be addressed in our next papers.

\section{Acknowledgements}

This research was partly financed by a grant from the University of Life Science in Lublin (TKF/MN/5 to AM).

\section{References}

1. CHEN G., YING M., LI W. Enzymatic conversion of waste cooking oils into alternative fuel - biodiesel. Applied biochemistry and biotechnology. 132, 911, 2006.

2. ZHANG W.B. Review on analysis of biodiesel with infrared spectroscopy. Renewable and Sustainable Energy Reviews. 16, 6048, 2012.

3. TARABET L., LOUBAR K., LOUNICI M.S., S. HANCHI, TAZEROUT M., Eucalyptus biodiesel as an alternative to diesel fuel: preparation and tests on DI diesel engine. BioMed Research International. 2012, 8, 2012.

4. LI M., ZHENG Y., CHEN Y., ZHU X. Biodiesel production from waste cooking oil using a heterogeneous catalyst from pyrolyzed rice husk. Bioresource technology. 154, 345, 2014.

5. TALEBIAN-KIAKALAIEHA.,AMIN N.A.S., MAZAHERI H. A review on novel processes of biodiesel production from waste cooking oil. Applied Energy. 104, 683, 2013.

6. ANAND P., SAXENA R.K. A comparative study of solventassisted pretreatment of biodiesel derived crude glycerol on growth and 1, 3-propanediol production from Citrobacter freundii. New Biotechnology. 29, 199, 2012.

7. SIDDIQUI N., AHMAD A. Infrared Spectroscopic Studies On Edible And Medicinal Oils. International Journal Of Science, Environment And Technology. 2, 1297, 2013.

8. WIJESEKARA R., NOMURA N., SATO S., MATSUMURA M. Pre-treatment and utilization of raw glycerol from sunflower oil biodiesel for growth and 1,3-propanediol production by Clostridium butyricum. Journal of chemical technology and biotechnology. 83, 1072, 2008.

9. ECHEVERRI D.A., CARDEÑO F., RIOS L.A. Glycerolysis of soybean oil with crude glycerol containing residual alkaline catalysts from biodiesel production. Journal of the American Oil Chemists' Society. 88, 551, 2011.

10. HAVLÍK P., SCHNEIDER U.A., SCHMID E., BÖTTCHER H., FRITZ S., SKALSKÝ R., AOKI K., DE CARA S., KINDERMANN G., KRAXNER F. Global land-use implications of first and second generation biofuel targets. Energy Policy. 39, 5690, 2011.

11. YAAKOB Z., MOHAMMAD M., ALHERBAWI M., ALAM Z., SOPIAN K. Overview of the production of biodiesel from waste cooking oil. Renewable and Sustainable Energy Reviews. 18, 184, 2013.

12. PIMENTEL D., MARKLEIN A., TOTH M.A., KARPOFF M.N., PAUL G.S., MCCORMACK R., KYRIAZIS J., KRUEGER T. Food versus biofuels: environmental and economic costs. Human ecology. 37, 1, 2009.
13. PIASECKAA., KRZEMIŃSKA I., TYS J. Physical methods of microalgal biomass pretreatment. Int. Agrophys. 28, 341, 2014.

14. PÉREZ-VÁZQUEZ A., ÁVILA-RESÉNDIZ C., VALDÉSRODRÍGUEZ O.A., GALLARDO-LÓPEZ F., GARCÍAPÉREZ E., RUIZ-ROSADO O. Effect of the soil water content on Jatropha seedlings in a tropical climate. International Agrophysics. 27, 351, 2013.

15. PHAN A.N., PHAN T.M. Biodiesel production from waste cooking oils. Fuel. 87, 3490, 2008.

16. GURUNATHAN B., RAVI A. Biodiesel production from waste cooking oil using copper doped zinc oxide nanocomposite as heterogeneous catalyst. Bioresource technology. 188, 124, 2015.

17. ZHANG Y., DUBE M., MCLEAN D., KATES M. Biodiesel production from waste cooking oil: 1 . Process design and technological assessment. Bioresource technology. 89, 1, 2003.

18. WEN Z., YU X., TU S.-T., YAN J., DAHLQUIST E. Biodiesel production from waste cooking oil catalyzed by $\mathrm{TiO} 2-\mathrm{MgO}$ mixed oxides. Bioresource technology. 101, 9570, 2010.

19. PATEL M.J., PATEL T.M., RATHOD G.R. Performance Analyis of CI Engine Using Diesel and Waste Cooking Oil Blend.

20. SHEINBAUM C., BALAM M.V., ROBLES G., DE LARREA S.L., MENDOZA R. Biodiesel from waste cooking oil in Mexico City. Waste Management \& Research. 0734242X15590471, 2015.

21. MOHAMMADSHIRAZI A., AKRAM A., RAFIEE S., KALHOR E.B. Energy and cost analyses of biodiesel production from waste cooking oil. Renewable and Sustainable Energy Reviews. 33, 44, 2014.

22. SZMIGIELSKI M., PIEKARSKI W., ANDREJKO D., SLASKA-GRZYWNA B., MASLOWSKI A., ZAJAC G., SAGAN A., JASKIEWICZ T., RACHANCZYK I. Recovery of fatty substances from post-frying waste materials by extraction with hexane. Przemysl Chemiczny. 93, 649, 2014.

23. PATIL P., DENG S., RHODES J.I., LAMMERS P.J. Conversion of waste cooking oil to biodiesel using ferric sulfate and supercritical methanol processes. Fuel. 89, 360, 2010.

24. RABELO S.N., FERRAZ V.P., OLIVEIRA L.S., FRANCA A.S. FTIR analysis for quantification of fatty acid methyl esters in biodiesel produced by microwave-assisted transesterification. International Journal of Environmental Science and Development. 6, 964, 2015.

25. CHATZIFRAGKOU A., DIETZ D., KOMAITIS M., ZENG A.P., PAPANIKOLAOU S. Effect of biodieselderived waste glycerol impurities on biomass and 1, 3 -propanediol production of Clostridium butyricum VPI 1718. Biotechnology and bioengineering. 107, 76, 2010.

26. PYLE D.J., GARCIA R.A., WEN Z. Producing docosahexaenoic acid (DHA)-rich algae from biodieselderived crude glycerol: effects of impurities on DHA production and algal biomass composition. Journal of Agricultural and Food Chemistry. 56, 3933, 2008.

27. VLACHOS N., SKOPELITIS Y., PSAROUDAKI M., KONSTANTINIDOU V., CHATZILAZAROU A., TEGOU E. Applications of Fourier transform-infrared spectroscopy to edible oils. Analytica Chimica Acta. 573, 459, 2006.

28. AULT A.P., POMEROY R. Quantitative investigations of biodiesel fuel using infrared spectroscopy: An instrumental analysis experiment for undergraduate chemistry students. Journal of Chemical Education. 89, 243, 2011. 
29. MAHAMUNI N.N., ADEWUYI Y.G. Fourier transform infrared spectroscopy (FTIR) method to monitor soy biodiesel and soybean oil in transesterification reactions, petrodiesel- biodiesel blends, and blend adulteration with soy oil. Energy \& Fuels. 23, 3773, 2009.

30. LAPUERTA M., HERREROS J.M., LYONS L.L., GARCÍACONTRERAS R., BRICEÑO Y. Effect of the alcohol type used in the production of waste cooking oil biodiesel on diesel performance and emissions. Fuel. 87, 3161, 2008.

31. ASHBY R.D., SOLAIMAN D.K., STRAHAN G.D. Efficient utilization of crude glycerol as fermentation substrate in the synthesis of poly (3-hydroxybutyrate) biopolymers. Journal of the American Oil Chemists' Society. 88, 949, 2011.

32. ATHALYE S.K., GARCIA R.A., WEN Z. Use of biodieselderived crude glycerol for producing eicosapentaenoic acid (EPA) by the fungus Pythium irregulare. Journal of Agricultural and Food Chemistry. 57, 2739, 2009.

33. O'DONNELL S., DEMSHEMINO I., YAHAYA M., NWANDIKE I., OKORO L. A Review on the Spectroscopic Analysis of Biodiesel. European International Journal of Science and Technology. 2, 137, 2013.

34. ZHANG J., CHEN S., YANG R., YAN Y., Biodiesel production from vegetable oil using heterogenous acid and alkali catalyst. Fuel. 89, 2939, 2010.

35. SPEIGHT J.G., Handbook of petroleum product analysis, John Wiley \& Sons, 2015.

36. MATWIJCZUK A., GÓRECKI A., KAMIŃSKI D., MYŚLIWA-KURDZIEL B., FIEDOR L., NIEWIADOMY A., KARWASZ G.P., GAGOŚ M. Influence of Solvent Polarizability on the Keto-Enol Equilibrium in 4-[5-(naphthalen-1-ylmethyl)-1， 3, 4-thiadiazol-2-yl] benzene-1, 3-diol. Journal of fluorescence. 25, 1867, 2015.

37. GAGOŚ M., MATWIJCZUK A., KAMIŃSKI D., NIEWIADOMY A., KOWALSKI R., KARWASZ G.P. Spectroscopic studies of intramolecular proton transfer in 2-(4-fluorophenylamino)-5-(2,4-dihydroxybenzeno)-1,3,4thiadiazole. Journal of fluorescence. 21, 1, 2011.

38. ALISKE M.A., ZAGONEL G.F., COSTA B.J., VEIGA W., SAUL C.K. Measurement of biodiesel concentration in a diesel oil mixture. Fuel. 86, 1461, 2007.

39. IOB A., BUENAFE R., ABBAS N.M. Determination of oxygenates in gasoline by FTIR. Fuel. 77, 1861, 1998.
40. OLIVEIRA J.S., MONTALVÃO R., DAHER L., SUAREZ P.A., RUBIM J.C. Determination of methyl ester contents in biodiesel blends by FTIR-ATR and FTNIR spectroscopies. Talanta. 69, 1278, 2006.

41. LIMA S.M., IZIDA T., FIGUEIREDO M.D.S., ANDRADE L.H.D.C., DEL RÉ P.V., JORGE N., BUBA E., ARISTONE F., Analysis of biodiesel and frying vegetable oils by means of FTIR photoacoustic spectroscopy. The European Physical Journal Special Topics. 153, 535, 2008.

42. YANG F., HANNA M.A., SUN R. Value-added uses for crude glycerol--a byproduct of biodiesel production. Biotechnology for biofuels. 5, 1, 2012.

43. HIDAWATI E.N., SAKINAH A.M. Treatment of glycerin pitch from biodiesel production. International Journal of Chemical and Environmental Engineering. 2, 2011.

44. BOSHUI C., YUQIU S., JIANHUA F., JIU W., JIANG W. Effect of cold flow improvers on flow properties of soybean biodiesel. Biomass and bioenergy. 34, 1309, 2010.

45. ARIES E., DOUMENQ P., ARTAUD J., ACQUAVIVA M., BERTRAND J. Effects of petroleum hydrocarbons on the phospholipid fatty acid composition of a consortium composed of marine hydrocarbon-degrading bacteria. Organic Geochemistry. 32, 891, 2001.

46. KLOFUTAR B., GOLOB J., Microorganisms in diesel and in biodiesel fuels. Acta chimica slovenica. 54, 744, 2007.

47. SUN L.M., LI M., MA C., LI P., LI J. Preparation and evaluation of lubricity additives for low sulfur diesel fuel. Energy \& Fuels. 2016.

48. TSENG C.H., WANG N., Fast analysis of fats, oils and biodiesel by FT-IR. Lipid Technology. 19, 39, 2007.

49. AL NUR M., ALI M., ALI A., IMTENAN S., MASJUKI H.H., VARMAN M., ARBAB M.I., SAJJAD H., FATTAH I.M.R., ABEDIN M.J., HASIB A.S.M., $10^{\text {th }}$ International Conference on Mechanical Engineering, ICME 2013Emission and Performance Improvement Analysis of Biodiesel-diesel Blends with Additives. Procedia Engineering. 90, 472, 2014.

50. MO X., LOTERO E., LU C., LIU Y., GOODWIN J.G. A Novel Sulfonated Carbon Composite Solid Acid Catalyst for Biodiesel Synthesis. Catalysis Letters. 123, 1, 2008. 